\title{
Viral vectored transmission blocking vaccines against Plasmodium falciparum
}

\author{
Melissa C Kapulu ${ }^{1 *}$, Sumi Biswas ${ }^{1}$, Andrew Blagborough ${ }^{2}$, Sarah C Gilbert ${ }^{1}$, Robert E Sinden ${ }^{2}$, Adrian VS Hill \\ From Parasite to Prevention: Advances in the understanding of malaria \\ Edinburgh, UK. 20-22 October 2010
}

\section{Background}

Transmission blocking vaccines (TBVs) target sexual develop $\hat{A} \neg$ ment of the parasite within the mosquito and aim to prevent transmission of malaria from one individual to another. Antibodies raised against Pfs 48/45, Pfs230 Region C, PfHAP2, and Anopheles gambiae Alanyl Aminopeptidase N1 (AgAPN1) proteins reduce transmission i.e. have transmission blocking activity [1-5]. Recombinant simian Adenovirus (AdC63 serotype) and Modified Vaccinia Ankara (MVA) viral vectors have been shown to induce high antibody titres to asexual parasite antigens in animal studies [6].

\section{Materials and methods}

Protein sequences for each of the antigens were codon optimised for expression in humans and cloned into shuttle vectors, which were then recombined with the parental virus and purified to obtain virus expressing the antigen of interest. Mice were vaccinated with AdC63 (i.m.), sera was taken after 2 weeks, and will be followed by an MVA boost (i.d.) eight weeks after the prime. Antibodies were assayed by a standardised ELISA, and transmission blocking activity assessed using a standardised membrane feeding assay (SMFA).

\section{Conclusion}

Induction of high antibody tires using this vaccine platform could be used together with other control measures to achieve elimination and/or eradication of the disease at a local or national level.

\footnotetext{
Author details

'Jenner Institute, University of Oxford, Roosevelt Drive, Oxford, OX3 7DQ, UK. ${ }^{2}$ Division of Cell and Molecular Biology, Sir Alexander Fleming Building, Imperia College London, Imperial College Road, London, SW7 2AZ, UK.

'Jenner Institute, University of Oxford, Roosevelt Drive, Oxford, OX3 7DQ, UK Full list of author information is available at the end of the article
}

Published: 20 October 2010

\section{References}

1. Dinglasan RR, Kalume DE, Kanzok SM, Ghosh AK, Muratova O, Pandey A, Jacobs-Lorena M: Disruption of Plasmodium falciparum development by antibodies against a conserved mosquito midgut antigen. Proc Natl Acad Sci USA 2007, 104:13461-6.

2. Chowdhury DR, Angov E, Kariuki T, Kumar N: A potent malaria transmission blocking vaccine based on codon harmonized full length Pfs48/45 expressed in Escherichia coli. PLoS One 2009, 4:e6352.

3. Bustamante PJ, Woodruff DC, Oh J, Keister DB, Muratova O, Williamson KC Differential ability of specific regions of Plasmodium falciparum sexualstage antigen, Pfs230, to induce malaria transmission-blocking immunity. Parasite Immunol 2000, 22:373-80.

4. Blagborough AM, Sinden RE: Plasmodium berghei HAP2 induces strong malaria transmission-blocking immunity in vivo and in vitro. Vaccine 2009, 27:5187-94.

5. Vermeulen AN, Ponnudurai T, Beckers PJ, Verhave JP, Smits MA, Meuwissen $\mathrm{JH}$ : Sequential expression of antigens on sexual stages of Plasmodium falciparum accessible to transmission-blocking antibodies in the mosquito. J Exp Med 1985, 162:1460-76.

6. Draper SJ, Moore AC, Goodman AL, Long CA, Holder AA, Gilbert SC, Hill F, Hill AV: Effective induction of high-titer antibodies by viral vector vaccines. Nat Med 2008, 14:819-821.

doi:10.1186/1475-2875-9-S2-O22

Cite this article as: Kapulu et al:: Viral vectored transmission blocking vaccines against Plasmodium falciparum. Malaria Journal 2010 9(Suppl 2):O22.

Submit your next manuscript to BioMed Central and take full advantage of:

- Convenient online submission

- Thorough peer review

- No space constraints or color figure charges

- Immediate publication on acceptance

- Inclusion in PubMed, CAS, Scopus and Google Scholar

- Research which is freely available for redistribution

Submit your manuscript at www.biomedcentral.com/submit

\section{Biomed Central}

(C) 2010 Kapulu et al; licensee BioMed Central Ltd. This is an open access article distributed under the terms of the Creative Commons Attribution License (http://creativecommons.org/licenses/by/2.0), which permits unrestricted use, distribution, and reproduction in any medium, provided the original work is properly cited. 